J. Lake Sci. (湖泊科学) , 2013, 25(5): 735-742

http: //www. jlakes. org. E-mail : jlakes@niglas.ac.cn

(c) 2013 by Journal of Lake Sciences

\title{
天津于桥水库夏季浮游生物调查及群落结构变化
}

\author{
武 丹,王海英, 张 震 \\ ( 天津市环境监测中心, 天津 300191)
}

\begin{abstract}
摘 要: 为了解于桥水库富营养化状况, 于 2011 年 7 月对于桥水库水质、浮游生物进行了调查. 结果表明,于桥水库综合 营养状态指数 $(T L I(\Sigma))$ 为 45.8 , 属于中营养水平. 浮游植物共计 8 门 59 种, 平均丰度为 $312.40 \times 10^{4} \mathrm{cells} / \mathrm{L}$, 平均生物 量为 $5.30 \mathrm{mg} / \mathrm{L}$, 以蓝、绿藻为主, 优势种为铜绿微囊藻 (Microcystis aeruginosa)、水华微囊藻 (Microcystis flos-aquae) 和单角 盘星藻具空变种 (Pediastrum simplex var. duodenarium). 浮游动物共计 16 种, 平均丰度为 $53.2 \mathrm{ind}$. / L , 平均生物量为 $11.58 \mathrm{mg} / \mathrm{L}$, 以长额象鼻蚤 (Bosmina longirostris) 和近邻剑水蚤 (Cyclops vicinus) 为优势种. 依据多样性指数、均匀度指数和 丰富度指数对于桥水库浮游生物进行评价, 表明于桥水库处于中 重污染水平, 这与采用 $T L I(\Sigma)$ 的评价结果较为一致. 与历史同期调查结果对比得出, 于桥水库浮游植物丰度、生物量增加, 浮游动物种类减少, 而生物量增加, 于桥水库由硅 蓝藻型水库过渡为硅 - 绿藻型水库, 最终向蓝-绿藻型水库演变.
\end{abstract}

关键词: 于桥水库;浮游生物; 群落结构;变化趋势

\section{Investigation of summer plankton community structure in Yuqiao Reservoir, Tianjin}

WU Dan, WANG Haiying \& ZHANG Zhen

( Tianjin Environmental Monitoring Center, Tianjin 300191, P. R. China)

Abstract:In July of 2011, the water quality and the structures of plankton community were investigated in Yuqiao Reservoir to evaluate its trophic state. The comprehensive trophic level index $(T L I(\Sigma))$ is 45.8 , which indicates the reservoir is mesotrophic. 59 phytoplankton species in total have been identified. The average phytoplankton abundance is $312.40 \times 10^{4}$ cells $/ \mathrm{L}$, and the average biomass is $5.30 \mathrm{mg} / \mathrm{L}$. The phytoplankton community is mainly composed by Cyanophyta and Chlorophyta. Microcystis aeruginosa, Microcystis flos-aquae and Pediastrum simplex var. duodenarium are dominated species. Total of 16 zooplankton species have been identified. The average zooplankton abundance is 53.2 ind. $/ \mathrm{L}$, and the average biomass is $11.58 \mathrm{mg} / \mathrm{L}$. The zooplankton community is mainly composed of Bosmina longirostris and Cyclops vicinus. Based upon the analyses of the Shannon-Wiener index, Pielou index and Margalef index, the reservoir is between medium pollution level and heavy pollution level, which is similar to the evaluation results of nutritional status using $\operatorname{TLI}(\Sigma)$. Comparative analysis has been carried out between historical data and the present investigation, and the results show that both abundance and biomass of phytoplankton have been increased, and zooplankton species have reduced while zooplankton biomass has increased. This indicates the evolution of Yuqiao Reservoir from a Bacillariophyta-Cyanophyta dominated reservoir into a Bacillariophyta-Chlorophyta dominated reservoir, and finally into a Cyanophyta-Chlorophyta dominated reservoir.

Keywords: Yuqiao Reservoir; plankton; community structure; variation trend

我国是水资源短缺的国家, 水库供水是缓解城市供水压力的重要途径. 随着经济的发展, 水库富营养化 问题日益突出. 水利部环境监测报告的数据显示, 目前我国有 $1 / 3$ 重要供水水库达到富营养化水平 ${ }^{[1]}$, 由此 导致的水库型饮用水源的安全问题备受关注. 浮游植物作为水库生态系统中重要的初级生产者, 对水体环 境的变化极为敏感,其种类、数量及群落结构的变化与一些环境因子的变化有着密切的关系,是反映水体富 营养化状况最重要的生物指标之一 ${ }^{[2]}$. 浮游动物是水库生态系统食物链中一个重要环节, 它通过摄食控制 浮游植物的数量, 来调节水体生态平衡, 在水库生态系统的结构和功能中起着重要的调控作用. 近年来, 部

* 2012-07-18 收稿;2013-02-25 收修改稿. 武丹,女,1984 年生, 硕士研究生, 工程师; E-mail: hjwudan@ 163. com. 
分水库发生了不同程度的水华 ${ }^{[3-4]}$, 随之, 关于水库浮游生物 (尤其是浮游植物) 的调查研究逐渐增多 ${ }^{[5-8]}$, 但 是,同步研究水库浮游植物和浮游动物群落结构变化的研究较少.

于桥水库位于天津北部蓟县城东 $4 \mathrm{~km}$ 处, 与河北省、北京市相邻, 距离天津市区 $115 \mathrm{~km}$. 自 1983 年引滦人 津输水工程通水后, 于桥水库作为中转蓄水库成为天津市人们生活饮用及工农业用水的主要来源, 是目前天 津市最重要的饮用水蓄存地. 根据水利部门提供的数据, 2009 年于桥水库实际供水量为 $5.9 \times 10^{8} \mathrm{~m}^{3}$, 服务总人 口达 748.16 万人. 然而, 由于历史性原因, 截止到 2009 年, 于桥水库周边一、二级保护区内仍分布着 6 个乡镇 47 个村落, 共计 16.28 万人, 其中一级保护区内居住 2.17 万人. 水库周边居民从事养殖捕捞、小型商业及农业耕作 等活动, 所产生的生活污水、禽畜粪便、固体垃圾、农田径流等加重了水库饮用水安全的风险. 随着当地旅游业的发 展, 餐馆农家院、小型加工企业兴起, 进一步威胁着水库饮用水安全. 本研究通过对于桥水库浮游生物调查, 全面了 解水库生物群落结构变化情况,探究于桥水库富营养化变化趋势,为于桥水库污染防治提供依据.

\section{1 材料与方法}

\section{1 采样点的布设}

2011 年 7 月, 在于桥水库的进水区、湖心区和出水区共设置 3 个采样点, 分别为点位 $1\left(40^{\circ} 1^{\prime} 45^{\prime \prime} \mathrm{N}\right.$, $\left.117^{\circ} 35^{\prime} 50^{\prime \prime} \mathrm{E}\right)$ 、点位 $2\left(40^{\circ} 2^{\prime} 23^{\prime \prime} \mathrm{N}, 117^{\circ} 32^{\prime} 41^{\prime \prime} \mathrm{E}\right)$ 和点位 $3\left(40^{\circ} 1^{\prime} 53^{\prime \prime} \mathrm{N}, 117^{\circ} 26^{\prime} 50^{\prime \prime} \mathrm{E}\right)$. 其中, 点位 1 为于桥水库 上游 3 条主要来水河流交汇处, 点位 3 为水库出口.

\section{2 样品的采集与处理}

应用 Professional Plus 多功能水质仪 (YSI) 测定水温 $(\mathrm{T}) 、 \mathrm{pH}$ 、溶解氧 $(\mathrm{DO})$; 用塞氏盘测定透明度 $(\mathrm{SD})$; 水样的采集及其它水质因子的分析测定参考文献 $[9]$, 水质因子包括高锰酸盐指数 $\left(\mathrm{COD}_{\mathrm{Mn}}\right)$ 、亚硝酸盐氮 $\left(\mathrm{NO}_{2}^{-}-\mathrm{N}\right)$ 、硝酸盐氮 $\left(\mathrm{NO}_{3}^{-}-\mathrm{N}\right)$ 、总氮 $(\mathrm{TN})$ 、总磷 $(\mathrm{TP})$ 和叶绿素 $\mathrm{a}(\mathrm{Chl} . \mathrm{a})$. 浮游植物、浮游动物样品的采集、 处理、定性及定量分析方法参照文献 [10-15].

\section{3 数据处理}

1.3.1 综合营养状态指数 参照国家环境保护部发布的《地表水环境质量评价办法 (试行) 》, 采用综合营养 状态指数 $T L I\left(\sum\right)$ 来评价水库的富营养化状况 ${ }^{[16]}$. 评价分级: $T L I(\Sigma)<30$, 贫营养; $30 \leqslant T L I(\Sigma) \leqslant 50$, 中营 养; $50<T L I\left(\sum\right) \leqslant 60$, 轻度富营养; $60<T L I(\Sigma) \leqslant 70$, 中度富营养; $T L I(\Sigma)>70$, 重度富营养.

1.3.2 生物学指标采用 Shannon-Wiener 指数 $\left(H^{\prime}\right)$ 、Pielou 均匀度指数 $(J)$ 和 Margalef 丰富度指数 $(d)$ 对浮 游植物多样性进行评价. 评价标准 ${ }^{[17]}$ 为: $H^{\prime}:>3$, 轻或无污染; $1 \sim 3$, 中污染; $0 \sim 1$, 重污染; $J: 0.5 \sim 0.8$, 轻或 无污染; $0.3 \sim 0.5$, 中污染; $0 \sim 0.3$, 重污染; $d:>3$, 轻或无污染; $1 \sim 3$, 中污染; $0 \sim 1$, 重污染. 优势种的确定采 用 Mcnaughton 优势度指数 $(Y), Y>0.02$ 的种类定为优势种, 公式为:

$$
\begin{gathered}
H^{\prime}=-\sum_{i=1}^{S} P_{i} \cdot \log _{2} P_{i}, P_{i}=N_{i} / N \\
J=H^{\prime} / \log _{2} S \\
d=(S-1) / \log _{2} N \\
Y=N_{i} / N \cdot f_{i}
\end{gathered}
$$

式中, $N_{i}$ 为第 $i$ 种的个体数, $N$ 为同一样品中的个体总数, $S$ 为种类总数, $f_{i}$ 为第 $i$ 种在各采样点出现的频率. 1.3 .3 相关性分析 对浮游植物数量、生物量与 8 项水质指标 (包括氮磷比) 进行 Pearson 相关性分析, 研究 浮游植物演变与水质因子的相互关系, 数据处理在 SPSS 15.0 平台上完成.

\section{2 结果与讨论}

\section{1 水质及营养状态评价}

于桥水库各项水质指标均达到或优于《地表水环境质量标准》( GB/T 3838-2002) III 类水质标准, 符合 饮用水要求, 但是营养盐含量较高, 水体富营养化态势较为明显. Vollenweider 等 ${ }^{[18]}$ 提出总磷含量处于 $0.010 \sim$ $0.035 \mathrm{mg} / \mathrm{L}$ 之间为中营养水平, 于桥水库总磷浓度为 $0.030 \mathrm{mg} / \mathrm{L}$, 显示于桥水库处于中营养水平. 按 Wetzel 
的营养类型划分方法 ${ }^{[19]}$, 叶绿素 a 浓度在 $2 \sim 15 \mathrm{mg} / \mathrm{m}^{3}$ 之间为中营养; 于桥水库的叶绿素 a 含量范围为 $11.0 \sim 12.7 \mathrm{mg} / \mathrm{m}^{3}$, 平均浓度为 $12.0 \mathrm{mg} / \mathrm{m}^{3}$, 表明于桥水库处于中营养水平. 经计算, 于桥水库 $T L I\left(\sum\right)$ 值为 45.8 ,参照分级,于桥水库处于中营养水平,与总磷、叶绿素 a 评价结果一致 (表 1 ).

表 1 于桥水库水质监测结果及综合营养状态指数

Tab. 1 Results of water quality and the comprehensive trophic level index in Yuqiao Reservoir

\begin{tabular}{lccccccccccc}
\hline 采样点 & $\mathrm{T} /{ }^{\circ} \mathrm{C}$ & $\mathrm{pH}$ & $\begin{array}{c}\mathrm{DO} / \\
(\mathrm{mg} / \mathrm{L})\end{array}$ & $\begin{array}{c}\mathrm{SD} / \\
\mathrm{cm}\end{array}$ & $\begin{array}{c}\mathrm{COD}_{\mathrm{Mn}} / \\
(\mathrm{mg} / \mathrm{L})\end{array}$ & $\begin{array}{c}\mathrm{NO}_{2}^{-}-\mathrm{N} / \\
(\mathrm{mg} / \mathrm{L})\end{array}$ & $\begin{array}{c}\mathrm{NO}_{3}^{-}-\mathrm{N} / \\
(\mathrm{mg} / \mathrm{L})\end{array}$ & $\begin{array}{c}\mathrm{TN} / \\
(\mathrm{mg} / \mathrm{L})\end{array}$ & $\begin{array}{c}\mathrm{TP} / \\
(\mathrm{mg} / \mathrm{L})\end{array}$ & $\begin{array}{c}\mathrm{Chl} . \mathrm{a} / \\
\left(\mathrm{mg} / \mathrm{m}^{3}\right)\end{array}$ & $T L I(\Sigma)$ \\
\hline 点位1 & 23.2 & 7.85 & 9.32 & 100 & 3.1 & 0.027 & 0.51 & 0.900 & 0.030 & 12.2 & 45.5 \\
点位2 & 23.8 & 8.03 & 8.78 & 100 & 3.1 & 0.026 & 0.50 & 0.880 & 0.030 & 11.0 & 45.1 \\
点位3 & 24.0 & 8.01 & 8.69 & 100 & 4.0 & 0.026 & 0.52 & 0.860 & 0.030 & 12.7 & 46.7 \\
平均值 & 23.7 & 7.96 & 8.93 & 100 & 3.4 & 0.026 & 0.51 & 0.880 & 0.030 & 12.0 & 45.8 \\
\hline
\end{tabular}

\section{2 浮游植物对营养状态的指示}

本次调查共鉴定出浮游植物 8 门 59 种 (包括属和变种), 其中绿藻门最多, 为 20 种, 占藻类总种数的 $33.9 \%$; 其次为硅藻门 19 种, 占 $32.2 \%$; 蓝藻门 9 种, 占 $15.3 \%$; 金藻门、裸藻门各 3 种, 均占 $5.1 \%$; 黄藻门、 甲藻门各 2 种,均占 $3.4 \%$; 隐藻门 1 种, 占 $1.7 \%$. 以优势度指数 $Y>0.02$ 确定为优势种, 于桥水库的优势种 有 3 种, 其中蓝藻门有 2 种, 为铜绿微囊藻 (Microcystis aeruginosa) $(Y=0.87)$ 和水华微囊藻 (Microcystis flosaquae) $(Y=0.06)$; 绿藻门有 1 种, 为单角盘星藻具空变种 (Pediastrum simplex var. duodenarium) $(Y=0.04)$, 3 种藻类的出现频率均达到 $100 \%$.

浮游植物丰度在水面相对开阔的点位 2 最高, 为 $344.81 \times 10^{4}$ cells/ L, 在人口点位 1 最低, 为 $258.78 \times$ $10^{4} \mathrm{cells} / \mathrm{L}$, 平均值为 $312.40 \times 10^{4} \mathrm{cells} / \mathrm{L}$. 就浮游植物的种群结构而言, 蓝藻的丰度占绝对优势, 其点位平均 值达到 $295.09 \times 10^{4}$ cells $/ \mathrm{L}$, 占藻类总数的 $94.4 \%$, 蓝藻的优势种一一铜绿微囊藻的丰度为 $272.65 \times 10^{4}$ cells $/ \mathrm{L}$, 占藻类总数的 $87.3 \%$. 浮游植物生物量范围为 $4.77 \sim 6.05 \mathrm{mg} / \mathrm{L}$, 平均值为 $5.30 \mathrm{mg} / \mathrm{L}, 3$ 个采样点 浮游植物生物量从高到低依次为点位 1 、点位 2 、点位 3 . 不同种类藻类的生物量差异较大, 其中绿藻生物量 最大, 点位平均值为 $2.69 \mathrm{mg} / \mathrm{L}$, 占藻类总数的 $50.7 \%$, 其次为蓝藻, 2 种藻类生物量总和占藻类总数的 $76.9 \%$ (表 2). 综合浮游植物丰度、优势种和生物量情况而言, 于桥水库为蓝一绿藻型.

表 2 于桥水库浮游生物的丰度和生物量

Tab. 2 Abundance and biomass of plankton in Yuqiao Reservoir

\begin{tabular}{|c|c|c|c|c|c|c|}
\hline & 门类 & 点位 1 & 点位 2 & 点位 3 & 平均值 & 所占比例 $/ \%$ \\
\hline \multirow{5}{*}{ 浮游植物丰度 $/\left(\times 10^{4}\right.$ cells $\left./ \mathrm{L}\right)$} & 蓝藻 & 233.22 & 329.88 & 322.17 & 295.09 & 94.4 \\
\hline & 绿藻 & 23.74 & 14.50 & 10.23 & 16.16 & 5.1 \\
\hline & 硅藻 & 1.41 & 0.23 & 0.78 & 0.81 & 0.2 \\
\hline & 其他 & 1.82 & 0.43 & 1.20 & 1.15 & 0.3 \\
\hline & 合计 & 258.78 & 344.81 & 333.60 & 312.40 & 100.0 \\
\hline \multirow[t]{5}{*}{ 浮游植物生物量/ $(\mathrm{mg} / \mathrm{L})$} & 蓝藻 & 1.07 & 1.51 & 1.57 & 1.39 & 26.2 \\
\hline & 绿藻 & 3.33 & 3.25 & 1.48 & 2.69 & 50.7 \\
\hline & 硅藻 & 1.19 & 0.07 & 0.92 & 0.73 & 13.7 \\
\hline & 其他 & 0.46 & 0.26 & 0.79 & 0.50 & 9.4 \\
\hline & 合计 & 6.05 & 5.09 & 4.77 & 5.30 & 100.0 \\
\hline \multirow[t]{4}{*}{ 浮游动物丰度/ (ind. /L) } & 节肢动物 & 113.9 & 34.9 & 7.07 & 52.0 & 97.7 \\
\hline & 线形动物 & 0.11 & 0.06 & 0.01 & 0.06 & 0.1 \\
\hline & 其他 & 0.72 & 2.69 & 0.02 & 1.1 & 2.2 \\
\hline & 合计 & 114.8 & 37.7 & 7.1 & 53.2 & 100.0 \\
\hline \multirow[t]{4}{*}{ 浮游动物生物量 $/(\mathrm{mg} / \mathrm{L})$} & 节肢动物 & 25.86 & 7.61 & 1.16 & 11.54 & 99.68 \\
\hline & 线形动物 & 0.01 & 0.003 & 0.0004 & 0.003 & 0.02 \\
\hline & 其他 & 0.02 & 0.08 & 0.0007 & 0.034 & 0.30 \\
\hline & 合计 & 25.89 & 7.69 & 1.16 & 11.58 & 100.0 \\
\hline
\end{tabular}


3 个采样点浮游植物的 $H^{\prime}$ 值处于 $0.65 \sim 1.09$ 范围内, 平均值为 0.84 , 表明于桥水库处于重污染水平; $J$ 值均小于 0.3 , 表明于桥水库处于重污染水平; $d$ 值范围为 $0.88 \sim 1.18$, 平均值为 1.04 , 表明于桥水库处于中 污染水平. 3 个指标综合评价结果表明,于桥水库处于中 重污染水平 (表 3 ).

表 3 于桥水库浮游生物群落特征参数值

Tab. 3 Characteristic parameters of plankton community in Yuqiao Reservoir

\begin{tabular}{|c|c|c|c|c|c|c|}
\hline \multirow{2}{*}{ 采样点 } & \multicolumn{3}{|c|}{ 浮游植物 } & \multicolumn{3}{|c|}{ 浮游动物 } \\
\hline & $H^{\prime}$ & $J$ & $d$ & $H^{\prime}$ & $J$ & $d$ \\
\hline 点位 1 & 1.09 & 0.21 & 1.18 & 1.30 & 0.39 & 0.54 \\
\hline 点位 2 & 0.77 & 0.16 & 0.88 & 1.68 & 0.43 & 0.92 \\
\hline 点位 3 & 0.65 & 0.13 & 1.04 & 0.90 & 0.30 & 0.55 \\
\hline 平均值 & 0.84 & 0.17 & 1.04 & 1.29 & 0.37 & 0.67 \\
\hline
\end{tabular}

\section{3 浮游动物对营养状态的指示}

本次调查共获得浮游动物 16 种, 其中, 节肢动物门 12 种, 占总种数的 $75 \%$; 线形动物门 3 种, 占 $18.8 \%$; 无节幼体 1 种, 占 $6.2 \%$. 出现率较高的是节肢动物门的长额象鼻蚤 (Bosmina longirostris)、大眼蚤 (Polyphemus sp.)、近邻剑水蚤 (Cyclops vicinus) 、小巧瘦猛水蚤 (Bryocamptus minutus) 和无节幼体 (Naupli$u s)$, 广泛分布于调查水域. 其它物种仅在个别点位出现. 以优势度指数 $Y>0.02$ 确定优势种有 3 种, 包括长 额象鼻蚤 $(Y=0.55)$ 、近邻剑水蚤 $(Y=0.39)$ 和无节幼体 $(Y=0.022)$.

浮游动物丰度范围为 $7.1 \sim 114.8 \mathrm{ind} . / \mathrm{L}$, 点位平均值为 $53.2 \mathrm{ind} . / \mathrm{L}$, 最大值出现在点位 1 , 最小值在点 位 3 , 该排序与浮游植物生物量大小排序一致. 就浮游动物的种群结构而言, 节肢动物占优, 各点位平均丰度 为 52.0 ind. $/ \mathrm{L}$, 占总数的 $97.7 \%$. 节肢动物的优势种为长额象鼻蚤和近邻剑水蚤, 分别占总数的 $54.8 \%$ 和 $38.9 \%$. 浮游动物生物量范围为 $1.16 \sim 25.89 \mathrm{mg} / \mathrm{L}$, 平均值为 $11.58 \mathrm{mg} / \mathrm{L}$, 生物量从大到小排序为: 点位 $1>$ 点位 $2>$ 点位 3 , 与浮游动物丰度排序一致. 节肢动物生物量最大, 点位平均值为 $11.54 \mathrm{mg} / \mathrm{L}$, 占总生物量的 99.68\%（表 2). 其中优势种近邻剑水蚤生物量最大, 占总生物量的 $71.4 \%$, 其次为长额象鼻蚤, 占 $25.2 \%$. 长额象鼻虫和近邻剑水蚤都是典型的富营养种类,表明于桥水库有明显的富营养化态势.

浮游动物群落 $H^{\prime}$ 值处于 $0.90 \sim 1.68$ 范围内, 平均值为 1.29 , 显示于桥水库处于中污染水平; $J$ 值范围 为 $0.30 \sim 0.43$, 平均值为 0.37 , 表明于桥水库处于中污染水平; $d$ 值范围为 $0.54 \sim 0.92$, 平均值为 0.67 , 表明于 桥水库处于重污染水平 (表 3). 3 个指标综合评价, 于桥水库处于中 重污染水平, 与浮游植物评价结果一致.

\section{4 于桥水库浮游生物群落结构变化}

7 月份水温较高, 适宜藻类生长, 暴发藻类水华的风险较高. 为初步探究近年来于桥水库浮游生物的群 落结构变化情况, 将本次调查结果与 3 次历史同期调查结果进行对比分析, 从种类组成、优势种、丰度、生物 量等方面探究近年来于桥水库浮游生物群落的动态变化.

2.4. 1 浮游植物群落结构变化 1986-2011 年期间, 于桥水库浮游植物种数波动较大 (表 4、图 1a). 其中, 1986 年 7 月至 1988 年 10 月调查到浮游植物 58 种, 1999 年 7 月、2000 年 7 月分别为 49 种和 31 种, 2011 年 7 月有所回升, 较 1986-1988 年调查结果增加 1 种. 1987 年 7 月, 于桥水库主要藻属硅藻、绿藻、蓝藻种数分 布较为均匀, 种数百分比均在 30\% 左右; 1999 年 7 月、2000 年 7 月调查期间, 于桥水库绿藻种数比例上升至 $50 \%$ 左右, 而硅藻、蓝藻种类比例均有所下降; 2011 年 7 月硅藻、绿藻所占比例均再次达到 30\% 左右, 而蓝藻 种类比例降低至 $15.3 \%$. 与 1986-1988 年调查结果相比, 于桥水库浮游植物总种数虽然变化不大, 但是主 要种属的分布比例发生了明显变化.

浮游植物丰度方面, 以 1987 年为参照点, 于桥水库浮游植物丰度呈明显的上升趋势, 2000 年 7 月、2011 年 7 月浮游植物丰度分别达到 1987 年 7 月的 1.5 倍和 3.4 倍. 生物量方面, 1986 年 7 月至 1988 年 10 月调 查期间, 于桥水库非结冰期的生物量均值为 $2.89 \mathrm{mg} / \mathrm{L}, 1999$ 年 7 月至 2000 年 7 月调查期间,生物量均值为 $3.73 \mathrm{mg} / \mathrm{L}$, 较前一次调查增长了 $29.1 \% .1999-2011$ 年, 于桥水库浮游植物生物量持续上升. 其中, 1999 年 7 月生物量为 $1.43 \mathrm{mg} / \mathrm{L}, 2000$ 年 7 月增长至 $4.01 \mathrm{mg} / \mathrm{L}$, 同比增长 1.8 倍, 2011 年 7 月为 $5.30 \mathrm{mg} / \mathrm{L}$, 较 2000 
年同期增长了 $32.2 \%$ (表 4).

1987 年以来于桥水库浮游植物群落结构变化显著, 富营养化趋势明显. 1987 年 7 月于桥水库以克罗顿 脆杆藻、铜绿微囊藻为优势种, 于桥水库为硅-蓝藻型; 1999 年 7 月、2000 年 7 月, 于桥水库优势种为颗粒直 链藻、克罗顿脆杆藻和单角盘星藻, 于桥水库为硅-绿藻型; 2011 年 7 月, 铜绿微囊藻、水华微囊藻、单角盘星 藻具空变种成为于桥水库的优势种, 于桥水库为蓝-绿藻型. 从各种属数量分布比例可以看出, 蓝藻丰度占 藻类总丰度的比例呈现显著上升趋势, 由 1999 年 7 月、2000 年 7 月的 $20 \%$ 左右陡然上升至 2011 年 7 月的 94. $4 \%$. 从生物量比例也可以看出, 硅藻生物量比例由 1987 年 7 月的 $59.3 \%$ 下降至 2011 年 7 月的 $13.7 \%$, 而蓝、绿藻的总生物量比例总体呈现上升趋势, 1987 年 7 月为 $29.2 \%, 1999 、 2000 、 2011$ 年同期均达到 60\% 以上, 分别为 $81.1 \% 、 64.1 \%$ 和 $76.9 \%$ (表 4). 总结而言, 夏季 (7 月份) 于桥水库由硅-蓝藻型水库过渡为 硅- 绿藻型, 最终向蓝-绿藻型水库演变. 通常来说, 富营养型湖泊常以绿藻、蓝藻类占优势, 由此可以看出, 于桥水库具有明显的富营养化趋势.

根据 1999 年 7 月、 2000 年 7 月、2011 年 7 月 3 次调查结果, 对于桥水库浮游植物丰度、生物量与 8 项水 质指标进行 Pearson 相关分析 (表 5), 结果表明: (1) 于桥水库浮游植物丰度与氮磷比呈极显著正相关, 与 $\mathrm{pH}$ 、高锰酸盐指数呈极显著负相关, 与总磷呈显著负相关; 2 浮游植物群落生物量与 $\mathrm{pH}$ 呈显著负相关; (3) 总氮、硝酸盐氮、叶绿素 $\mathrm{a}$ 和透明度与于桥水库浮游植物丰度或生物量没有显著相关性.

一般认为, 蓝藻水华是水体中氮、磷含量增加所致, 与水华形成有关的氮磷比例备受关注. Smith ${ }^{[20]}$ 提出 如果湖泊的氮磷摩尔比低于 29 , 蓝藻将会占据优势. Redfield ${ }^{[21]}$ 则认为氮磷比值为 7 是判断藻类生长限制因 子的阈值. 本研究中, 于桥水库 3 次调查结果氮磷比均值分别为 $11.63 、 9.19$ 和 29.33 (表 6). 因此, 磷是于桥 水库藻类生长的限制因子, 这与田志强等 ${ }^{[22]}$ 对于桥水库的研究结论一致. 本研究相关性分析结果还显示 浮游植物丰度与总磷呈显著相关关系, 这与磷为于桥水库藻类生长限制因子的结论相吻合. 还有研究认 为并非单纯的总磷或总氮浓度对藻类生长有直接影响, 而是氮磷比在某些范围显著影响藻类生长 ${ }^{[23]}$. Young 等 ${ }^{[24]}$ 提出在总氮浓度大于 $0.20 \mathrm{mg} / \mathrm{L}$, 总磷浓度大于 $0.02 \mathrm{mg} / \mathrm{L}$ 的水体中, 营养盐对藻类的限制作 用会下降, 其他因素会影响藻类营养盐的利用. 如表 5 所示, 于桥水库营养盐含量较高, 总氮浓度范围为 $0.579 \sim 0.880 \mathrm{mg} / \mathrm{L}$, 总磷浓度为 $0.030 \sim 0.071 \mathrm{mg} / \mathrm{L}$, 而浮游植物密度与氮磷比相关性较其与总磷的相 关性更为显著, 推测在氮、磷浓度较高的浓度下, 氮磷比对浮游植物生长的影响较单纯的氮、磷浓度的影 响更为显著.

于桥水库浮游植物丰度与高锰酸盐指数、总磷分别呈极显著、显著负相关. 3 次调查结果显示, 于桥水库 浮游植物丰度逐次增加, 2011 年 7 月浮游植物丰度为 1987 年的 3.4 倍, 而总磷浓度由 $0.071 \mathrm{mg} / \mathrm{L}$ 降至 $0.030 \mathrm{mg} / \mathrm{L}$, 高锰酸盐指数由 $5.1 \mathrm{mg} / \mathrm{L}$ 降至 $3.4 \mathrm{mg} / \mathrm{L}$ (表 6 ). 分析其原因, 铜绿微囊藻具有超量积累磷的能 力, 其生长状态好时可以迅速吸收环境水体中磷的含量, 并在体内以聚合磷酸盐的形式存储 ${ }^{[25]} .2011$ 年调 查期间铜绿微囊藻丰度占藻类总丰度的比例高达 $87.3 \%, 7$ 月正值藻类增殖期, 大量藻类尤其是铜绿微囊 藻的生长消耗了水体中大量的营养元素和有机物质, 短期时间内起到了净化水体的作用. 这与凌㫋瑾等 ${ }^{[26]}$ 、 赖廷和等 ${ }^{[27]}$ 的相关研究结果吻合.

吴剑等 ${ }^{[28]}$ 研究了铜绿微囊藻生长过程对培养液 $\mathrm{pH}$ 的影响, 发现处于延迟期和对数生长期的铜绿微囊 藻使培养液的 $\mathrm{pH}$ 上升, 而稳定期或衰亡期的铜绿微囊藻使培养液的 $\mathrm{pH}$ 降低. 本研究中浮游植物丰度、生物 量与 $\mathrm{pH}$ 均呈显著负相关, 可能是大量处于稳定生长期的铜绿微囊藻影响所致.

2.4.2 浮游动物群落结构变化 1986-1987 年、1999-2000 年、2011 年 7 月调查结果相比较, 于桥水库浮游 动物的种数逐次减少 (图 1b、表 7). 与 1986-1987 年相比, 2011 年 7 月于桥水库原生动物种数减少了 11 种, 线形动物减少 16 种, 节肢动物减少 3 种, 无节幼体种类变化不大. 各种属种数比例发生变化, 节肢动物种 数所占比例上升. 其中, 1999-2000 年节肢动物种数比例较 1986-1987 年增长了 10.7\%, 2011 年 7 月较 1999-2000 年增长了 $31.0 \% .2011$ 年 7 月原生动物、线形动物种数比例有所下降, 分别比 1986-1987 年下 降了 $24.4 \%$ 和 $23.4 \%$.

于桥水库浮游动物的丰度呈现下降趋势, 而生物量则明显增加. 1986-1987 年于桥水库浮游动物丰度为 368 ind. /L, 1999-2000 年降低至 208 ind. / L 降幅为 $43.5 \%$. 2000 年 7 月浮游动物丰度为 280 ind. $/ \mathrm{L}, 2011$ 年 
7 月为 $53 \mathrm{ind} . / \mathrm{L}$, 同比降低了 $81.0 \%$. 从生物量来看, $1999-2000$ 年为 $8.28 \mathrm{mg} / \mathrm{L}$, 是 $1986-1987$ 年调查结果 的 5.0 倍. 2000 年 7 月生物量为 $7.61 \mathrm{mg} / \mathrm{L}, 2011$ 年 7 月增长至 $11.58 \mathrm{mg} / \mathrm{L}$, 同比增长 $52.2 \%$, 其中节肢动物生 物量所占比例由 $94.0 \%$ 增加至 $99.68 \%$. 于桥水库浮游动物丰度降低而生物量增加, 与浮游动物群落个体较小 的原生动物、线形动物减少, 而节肢动物比例增大有关, 说明库区浮游动物群落结构组成发生了较大变化.

表 4 1987－2011 年期间于桥水库浮游植物群落结构变化

Tab. 4 The variation of phytoplankton structure in Yuqiao Reservoir during 1987 - 2011

\begin{tabular}{|c|c|c|c|c|c|c|c|}
\hline \multirow{2}{*}{ 采样时间 } & \multirow{2}{*}{ 种数 } & \multirow{2}{*}{ 优势种 } & \multirow{2}{*}{$\begin{array}{c}\text { 丰度 } / \\
\left(\times 10^{4} \text { cells } / \mathrm{L}\right.\end{array}$} & \multirow{2}{*}{$\begin{array}{l}\text { 生物量/ } \\
\text { ( mg/L) }\end{array}$} & \multicolumn{3}{|c|}{ 主要种属百分比 (硅藻/绿藻/蓝藻, \% ) } \\
\hline & & & & & 种数 & 丰度 & 生物量 \\
\hline 1987 年 7 月 & $58^{1)}$ & $\begin{array}{l}\text { 硅藻、蓝藻 (克罗顿脆 } \\
\text { 杆藻、铜绿微囊藻) }\end{array}$ & 92.5 & $(2.89)^{2)}$ & $34.5 / 31.0 / 25.9$ & - & $59.3 / 4.9 / 24.3$ \\
\hline 1999 年 7 月 & 49 & $\begin{array}{l}\text { 硅藻、绿藻 (颗粒直链 } \\
\text { 藻、克罗顿脆杆藻、单 } \\
\text { 角盘星藻具空变种) }\end{array}$ & 39.8 & 1.43 & $14.3 / 51.0 / 24.5$ & $31.2 / 47.2 / 20.1$ & $10.5 / 9.1 / 72.0$ \\
\hline 2000 年 7 月 & 31 & $\begin{array}{l}\text { 硅藻、绿藻 (颗粒直链 } \\
\text { 藻、克罗顿脆杆藻、单 } \\
\text { 角盘星藻具空变种) }\end{array}$ & 135.6 & $\begin{array}{c}4.01 \\
(3.73)^{3)}\end{array}$ & $22.6 / 48.4 / 16.1$ & $48.4 / 30.2 / 19.3$ & $32.2 / 26.7 / 37.4$ \\
\hline 2011 年 7 月 & 59 & $\begin{array}{l}\text { 蓝藻、绿藻 (铜绿微囊 } \\
\text { 藻、水华微囊藻、单角 } \\
\text { 盘星藻具空变种) }\end{array}$ & 312.40 & 5.30 & $32.2 / 33.9 / 15.3$ & $0.2 / 5.1 / 94.4$ & $13.7 / 50.7 / 26.2$ \\
\hline
\end{tabular}

1) 1986 年 7 月至 1988 年 10 月调查期间的所有浮游植物种数;2) 1986 年 7 月至 1988 年 10 月调查期间,于桥水库非结 冰期的浮游植物生物量均值为 $2.89 \mathrm{mg} / \mathrm{L}$; 3$) 1999$ 年 7 月至 2000 年 7 月调查期间, 于桥水库的浮游植物生物量均值为 $3.73 \mathrm{mg} / \mathrm{L}$.

表 5 于桥水库水质因子与浮游植物丰度、生物量的 Pearson 相关性分析

Tab. 5 Pearson relation analysis between water quality factors and the abundance, biomass of phytoplankton in Yuqiao Reservoir

\begin{tabular}{|c|c|c|c|c|c|c|c|c|c|c|}
\hline & $\mathrm{pH}$ & $\mathrm{TN}$ & $\mathrm{TP}$ & $\mathrm{COD}_{\mathrm{Mn}}$ & SD & $\mathrm{NO}_{3}^{-}-\mathrm{N}$ & Chl. a & $\mathrm{TN} / \mathrm{TP}$ & $\begin{array}{c}\text { 浮游植物 } \\
\text { 丰度 }\end{array}$ & $\begin{array}{c}\text { 浮游植物 } \\
\text { 生物量 }\end{array}$ \\
\hline $\mathrm{pH}$ & 1 & & & & & & & & & \\
\hline $\mathrm{TN}$ & -0.463 & 1 & & & & & & & & \\
\hline $\mathrm{TP}$ & $0.705^{* *}$ & -0.155 & 1 & & & & & & & \\
\hline $\mathrm{COD}_{\mathrm{Mn}}$ & $0.860^{* *}$ & -0.342 & $0.672 *$ & 1 & & & & & & \\
\hline SD & -0.304 & 0.427 & -0.337 & -0.291 & 1 & & & & & \\
\hline $\mathrm{NO}_{3}^{-}-\mathrm{N}$ & -0.173 & 0.380 & 0.107 & -0.092 & -0.304 & 1 & & & & \\
\hline Chl. a & 0.569 & -0.371 & $0.719^{*}$ & $0.663^{*}$ & 0.129 & $-0.711^{*}$ & 1 & & & \\
\hline $\mathrm{TN} / \mathrm{TP}$ & $-0.933^{* *}$ & $0.572 *$ & $-0.827^{* *}$ & $-0.835 * *$ & $* 0.357$ & 0.142 & -0.708 * & * 1 & & \\
\hline 浮游植物丰度 & $-0.811^{* *}$ & 0.160 & $-0.587^{*}$ & $-0.765 * *$ & $* 0.176$ & -0.186 & -0.333 & $0.739^{* *}$ & 1 & \\
\hline 浮游植物生物量 & $-0.590 *$ & -0.005 & -0.495 & -0.548 & 0.152 & -0.495 & 0.056 & 0.543 & 0.840 ** & 1 \\
\hline
\end{tabular}

*表示显著相关, $P<0.05 ; * *$ 表示极显著相关, $P<0.01$ (双尾检验).

表 $61999-2011$ 年期间于桥水库水质因子变化

Tab. 6 The variation of water quality factors in Yuqiao Reservoir during 1999-2011

\begin{tabular}{ccccccrrr}
\hline 采样时间 & $\mathrm{pH}$ & $\begin{array}{c}\mathrm{TN} / \\
(\mathrm{mg} / \mathrm{L})\end{array}$ & $\begin{array}{c}\mathrm{TP} / \\
(\mathrm{mg} / \mathrm{L})\end{array}$ & $\begin{array}{r}\mathrm{COD}_{\mathrm{Mn}} / \\
(\mathrm{mg} / \mathrm{L})\end{array}$ & $\begin{array}{r}\mathrm{SD} / \\
\mathrm{cm}\end{array}$ & $\begin{array}{r}\mathrm{NO}_{3}^{-}-\mathrm{N} / \\
(\mathrm{mg} / \mathrm{L})\end{array}$ & $\begin{array}{c}\mathrm{Chl} . \mathrm{a} / \\
\left(\mathrm{mg} / \mathrm{m}^{3}\right)\end{array}$ & $\mathrm{TN} / \mathrm{TP}$ \\
\hline 1999 年7 月 & 8.74 & 0.826 & 0.071 & 5.1 & 94 & 0.635 & 17.2 & 11.63 \\
2000 年7 & 8.78 & 0.579 & 0.063 & 4.8 & 98 & 0.220 & 25.1 & 9.19 \\
2011 年7 7 & 7.96 & 0.880 & 0.030 & 3.4 & 100 & 0.510 & 12.0 & 29.33 \\
\hline
\end{tabular}

浮游动物各种属分布比例变化显著, 优势种有一定程度的改变. 1986-1987 年于桥水库原生动物丰度 

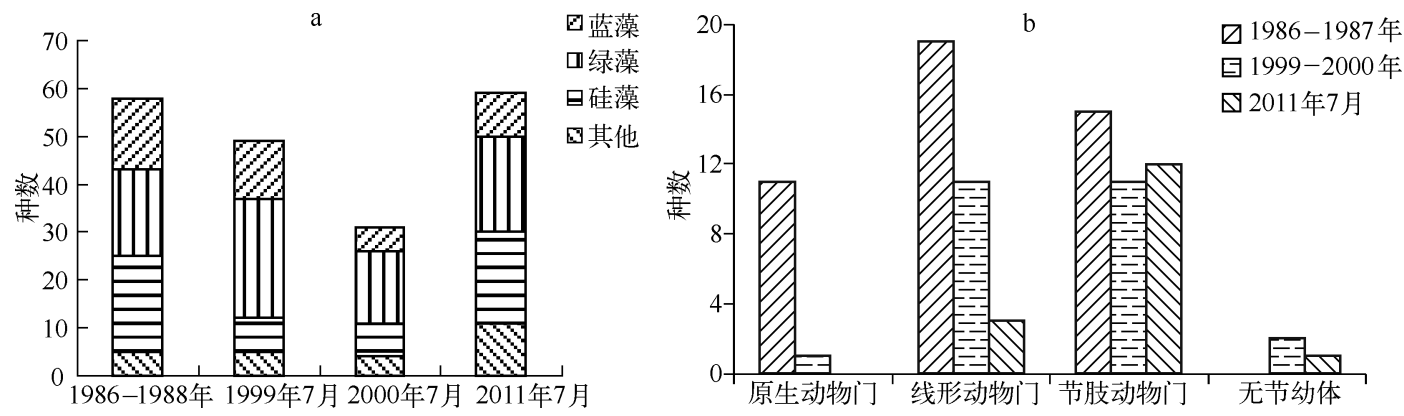

图 1 1986-2011 年于桥水库主要藻类 $(\mathrm{a})$ 和浮游动物 $(\mathrm{b})$ 种数的变化

Fig. 1 Changes of main algae species(a) and zooplankton species(b) in Yuqiao Reservoir during 1986 - 2011

最大, 为 275 ind. $/ \mathrm{L}$, 占总丰度的 $74.7 \%$; 而 2011 年 7 月于桥水库节肢动物丰度占优势, 达到总丰度的 $97.7 \%$. 以生物量计优势种, 1986-1987 年、1999-2000 年期间于桥水库优势种包括轮虫和节肢动物, 而 2011 年 7 月于桥水库优势种仅为节肢动物.

总之, 本次调查结果与历史调查结果相比, 浮游植物丰度、生物量增加, 蓝、绿藻占优势; 浮游动物种类 减少, 而生物量增加. 这与东太湖 1970s 初期至 2008 年底浮游生物的变化趋势一致 ${ }^{[29]}$, 说明于桥水库正处 于向富营养化过渡的阶段.

表 7 1986-2011 年期间于桥水库浮游动物群落结构变化

Tab. 7 The variation of zooplankton community structure in Yuqiao Reservoir during 1986-2011

\begin{tabular}{|c|c|c|c|c|c|c|}
\hline \multirow[t]{2}{*}{ 采样时间 } & \multirow[t]{2}{*}{ 种数 } & \multirow[t]{2}{*}{ 优势种 } & \multirow{2}{*}{$\begin{array}{l}\text { 丰度/ } \\
\text { (ind. /L) }\end{array}$} & \multirow{2}{*}{$\begin{array}{l}\text { 生物量/ } \\
(\mathrm{mg} / \mathrm{L})\end{array}$} & \multicolumn{2}{|c|}{$\begin{array}{c}\text { 种属百分比 (原生动物/线形动物/ } \\
\text { 节肢动物/无节幼体, \% ) }\end{array}$} \\
\hline & & & & & 种数 & 生物量 \\
\hline $1986-1987$ 年 $^{1)}$ & 45 & $\begin{array}{l}\text { 轮虫、节肢动物( 卜氏晶囊轮虫、僧帽 } \\
\text { 蚤、近邻剑水蚤、右突新镖蚤) }\end{array}$ & 368 & 1.66 & $24.4 / 42.2 / 33.3 / 0$ & - \\
\hline $1999-2000$ 年 $^{2)}$ & 25 & $\begin{array}{l}\text { 轮虫、节肢动物 (嗑状臂尾轮虫、僧 } \\
\text { 帽蚤、透明蚤、广布中剑蚤) }\end{array}$ & 208 & 8.28 & 4. $0 / 44.0 / 44.0 / 8.0$ & - \\
\hline 2000 年 7 月 & - & - & 280 & 7.61 & - & $0 / 4.5 / 94.0 / 1.6$ \\
\hline 2011 年 7 月 & 16 & 节肢动物 (长额象鼻蚤、近邻剑水蚤) & 53 & 11.58 & $0 / 18.8 / 75.0 / 6.3$ & $0 / 0.02 / 99.68 / 0.30$ \\
\hline
\end{tabular}

1) 1986 年 7 月至 1987 年 11 月逐月调查结果;2) 1999 年 $8 、 9 、 11$ 月及 2000 年 $4 、 7$ 月调查结果.

\section{3 结论}

1) 本次调查于桥水库浮游植物 8 门 59 种 (包括属和变种), 优势种为铜绿微囊藻、水华微囊藻和单角 盘星藻具空变种. 浮游植物平均丰度为 $312.40 \times 10^{4} \mathrm{cells} / \mathrm{L}$, 平均生物量为 $5.30 \mathrm{mg} / \mathrm{L}$, 以蓝、绿藻为主. 总体 而言, 于桥水库为蓝一绿藻型. 于桥水库浮游动物共计 16 种, 优势种为长额象鼻蚤、近邻剑水蚤和无节幼体. 浮游动物丰度平均值为 53.2 ind. / L , 平均生物量为 $11.58 \mathrm{mg} / \mathrm{L}$, 丰度和生物量组成以长额象鼻虫和近邻剑 水蚤为主,两者均为富营养化水体指示种, 表明于桥水库富营养化趋势明显.

2) 2011 年 7 月,于桥水库综合营养状态指数 $T L I\left(\sum\right)$ 值为 45.8 , 表明于桥水库处于中营养水平. 采用 Shannon-Wiener 多样性指数、Pielou 均匀度指数和 Margalef 丰富度指数分别对浮游植物、浮游动物进行评价, 结果为于桥水库处于中 重污染水平, 与于桥水库处于中营养水平、具有富营养化趋势的结论较为一致.

3 ) 与历史同期调查结果相比, 于桥水库浮游植物丰度、生物量增加, 蓝、绿藻为优势种群, 浮游动物种类 减少, 而生物量增加, 富营养化指示种普遍存在. 于桥水库由硅一蓝藻型水库过渡为硅一绿藻型, 最终向蓝一绿 藻型水库演变. Pearson 相关分析表明, 于桥水库浮游植物丰度与氮磷比呈极显著正相关, 与 $\mathrm{pH}$ 、高锰酸盐指 数呈极显著负相关, 与总磷呈显著负相关;浮游植物群落总生物量与 $\mathrm{pH}$ 呈显著负相关. 
4) 本次调查研究了于桥水库夏季浮游生物群落结构变化、优势种演替及水体富营养化状况等方面内 容. 但本次调查数据较为单薄, 无法精确地揭示于桥水库浮游生物群落结构的季节、年际变化趋势. 下一步 工作将加密于桥水库浮游生物的监测频次, 开展季节性监测, 并加大时间跨度, 形成较为连续的监测时间序 列, 构建于桥水库浮游生物数据库, 以便更为系统地反映于桥水库浮游生物的演变趋势.

致谢: 天津科技大学海洋科学与工程学院刘宪斌院长和赵兴贵老师在浮游生物定性、定量分析方面给予了 极大的指导和帮助, 在此致以衰心感谢.

\section{4 参考文献}

[ 1 ] 韩博平. 中国水库生态学研究的回顾与展望. 湖泊科学, 2010,22(2) :151-160.

[ 2 ] Reynolds CS. The ecology of phytoplankton. Cambridge: Cambridge University Press, 2006:38-90.

[ 3 ] 秦伯强, 王小冬, 汤祥明等. 太湖富营养化与蓝藻水华引起的饮用水危机一一原因与对策. 地球科学进展, 2007,22 (9) :896-906.

[ 4 ] 刘 蕾, 雷腊梅, 肖利娟等. 一座南亚热带小型水库水体营养状态与浮游植物的季节变化. 生态科学, 2008,27(2): $71-76$.

[ 5] 孔令惠, 蔡庆华, 徐耀阳等. 丹江口水库浮游轮虫群落季节变动特征及其与环境因子的关系. 湖泊科学, 2010,22 (6) :941-949.

[6] 吕光俊, 熊邦喜, 陈 朋. 华中地区 4 座不同类型水库浮游植物的群落结构和多样性. 中国水产科学, 2012,19(4): 690-699.

[ 7 ] 岳 强, 黄 成, 史元康等. 粤北 2 座饮用水源地水库的富营养化与浮游植物群落动态. 生态环境学报, 2012,21 (3) :503-508.

[8] 申恒伦, 蔡庆华, 邵美玲等. 三峡水库香溪河流域梯级水库浮游植物群落结构特征. 湖泊科学, 2012, 24 (2): 197-205.

[ 9 ] 国家环境保护总局. 水和废水监测分析方法. 北京:中国环境科学出版社,2002.

[10］金相灿,屠清瑛. 湖泊富营养化调查规范. 北京:中国环境科学出版社,1990.

[11] 章宗涉,黄祥飞. 淡水浮游生物研究方法. 北京:科学出版社,1991.

[12] 胡鸿钧,魏印心. 中国淡水藻类——系统、分类及生态. 北京:科学出版社,2006.

[13] 黎尚豪, 毕列爵. 中国淡水藻志. 北京:科学出版社,1998.

[14] 沈嘉瑞. 中国动物志一一节肢动物门甲壳纲:淡水桡足类. 北京:科学出版社, 1979 .

[15] 蒋敦治,堵南山. 中国动物志一一节肢动物门甲壳纲: 淡水枝角类. 北京: 科学出版社, 1979:153-155.

[16] 林秋奇, 韩博平. 水库生态系统特征研究及其在水库水质管理中的应用. 生态学报,2001,21 (6): 1034-1040.

[17］黄祥飞. 湖泊生态调查观测与分析. 北京: 中国标准出版社,2000:72-79.

[18] Vollenweider RA, Kerekes J. Eutrophication of waters: monitoring, assessment and control. Paris: OECD, 1982.

[19] Wetzel RG. Limnology. Fort Worth: Saunders College Publishing, 1983.

[20] Smith VH. Low Nitrogen to phosphorus ratios favor dominance by blue green algae in lake phytoplankton. Science, 1983, 221 :669-671.

[21] Redfield AC. The biological control of chemical factors in the environment. American Scientist, 1958,46(3):205-222.

[22] 田志强, 田秉晖, 辛丽花等. 于桥水库秋季浮游植物群落结构与水质因子的关系. 环境污染与防治, 2011, 33(5): 64-68.

[23] 姚恩亲, 杨晓红, 张海燕等. 基于典范对应分析的南太湖人湖口浮游植物一环境关系研究. 地质灾害与环境保护, $2010,21(4): 57-62$.

[24] Young K, Morse GK, Scrimchaw MD et al. The relation between phosphorus and eutrophication in the Thames catchment, UK. Science of the Total Environment, 1999,228:157-183.

[25] 邹 迪, 肖 琳, 杨柳燕等. 不同氮磷比对铜绿微囊藻及附生假单胞菌磷代谢的影响. 环境化学, 2005, 24 (6) : 647-650.

[26] 凌旌瑾, 顾咏洁, 许春梅等. 黄浦江和苏州河的着生藻类与水质因子关系的多元分析. 环境科学研究, 2008, 21 (5): 184-189.

[27] 赖廷和, 邱绍芳. 北海近岸水域浮游植物群落结构及数量周年变化特征. 海洋通报,2005,24(5):27-32.

[28] 吴 剑, 孔 倩, 杨柳燕等. 铜绿微囊藻生长对培养液 $\mathrm{pH}$ 值和氮转化的影响. 湖泊科学, 2009,21(1):123-127.

[29］曾庆飞,谷孝鸿, 周露洪等. 东太湖水质污染特征研究. 中国环境科学,2011,31(8):1355-1360. 